\title{
The global Campanian-Maastrichtian stage boundary
}

Université P. \& M. Curie, Unité de Géochronologie et Sédimentologie Océanique; 4, Place Jussieu, Case 119 A, F75252, Paris Cedex 05, France.

The Campanian-Maastrichtian boundary has never been formally defined; in addition to a number of other less common uses two current practices exist: they consider the first occurrence ( $F O$ ) of the boreal endemic key taxon Belemnella lanceolata (belemnite) and the last occurrence ( $L O)$ of the oceanic Radotruncana calcarata (planktonic foraminifera). Based on indirect correlation, the boreal FO is distinctly younger compared to the Tethyan LO.

The Tethyan section near Dax (Tercis les Bains*, SW France) has been studied in detail for the last eight years by a Maastrichtian Working Group. Physicochemical data and biostratigraphical characterisation on 18 fossil groups have been established. The selected section is exceptionally well located in a key area allowing correlation between the Boreal and Tethyan Realms, western Europe and North America, the oceanic and platform environments, the marine and continental successions.

Correlation with regard to historical stratotypes of Charente (France) and Limburg (Belgium and the Netherlands), key sections in the Boreal (mostly Kronsmoor, N. Germany) and Tethyan Realms (mostly Navarra, N. Spain and Gubbio, Apennines) have been studied and discussed. The here-presented boundary point is consistent with the content of historical stratotypes; a rather precise connection with the records in the Apennines and N Germany allows to locate the Tercis boundary in these two areas and, reversely, to correlate stratigraphical information from these areas to the Tercis section near Dax. The new definition was voted and ratified between 1999 and 2001.

\section{Introduction}

In 2000, none out of the twelve stage boundaries of the Cretaceous System was defined using the concept of Global boundary Standardstratotype Section and Point (GSSP). The problem was discussed during two meetings (Birkelund et al., 1984; Dhondt, 1995; Rawson et al., 1996).

\footnotetext{
* The spelling "Tercis les Bains" (and not Tercis-les-Bains as used on some maps) is the one recommended by the territorial authority. In practice, the whole name is rarely used and citizens in the Dax area simply say Tercis (pronunciation: [tercis] insisting strongly on the last $\mathrm{s}$ ).
}

The Maastrichtian Working Group (MWG) of the Subcommission on Cretaceous Stratigraphy, in charge of the proposal of definition of the Campanian-Maastrichtian boundary, was set up following the proposal to consider the Tercis section as a candidate for this definition. From then on, the number of members of the MWG - the scientists who contributed to the study of the boundary - constantly increased; a first review of the results was presented in 1995 (Odin, 1995).

A major problem occurred in many practical definitions coexisting. The preliminary proposals (Birkelund et al., 1984) mentioned six taxa, the ranges of which could be of use to locate and correlate the boundary:

- evolutionary appearance of the ammonite Hoploscaphites constrictus (J. Sowerby, 1817);

- evolutionary appearance of the ammonite Pachydiscus (Pachydiscus) neubergicus (von Hauer, 1858);

- evolutionary appearance of the belemnite Belemnella lanceolata (Schlotheim, 1813);

- evolutionary appearance of the foraminifera Globotruncana falsostuarti Sigal, 1952;

- extinction of the foraminifera Radotruncana calcarata (Cushman, 1927);

- extinction of the calcareous nannofossil Quadrum trifidum (Stradner in Stradner and Papp, 1961) Hattner and Wise, 1980;

Three other biohorizons were suggested, discussed, or used later (Rawson et al., 1996):

- appearance (Atabekian, 1995) of Nostoceras (Nostoceras) hyatti Stephenson, 1941;

- extinction of Nostoceras hyatti;

- extinction of the calcareous nannofossil Aspidolithus parcus constrictus (Hattner, Wind and Wise, 1980) Perch-Nielsen, 1984.

The chronological succession of the nine biohorizons slightly varies from one place to another; they were never found altogether (nor a majority of them) in a single section, so that chronological comparisons have been indirect up to now. However, in the record at Tercis, eight out of the nine criteria can be observed (Odin, 2001, chapter F2). Thus, the nine biohorizons can be confidently placed as follows from top to bottom:

$\mathrm{n}^{\circ} 1$ (last occurrence-LO-of the calcareous nannofossil Aspidolithus parcus constrictus) is the most recent (about $1.8 \mathrm{Ma}$ after the deposition of the preferred boundary horizon according to data from Tercis);

$\mathrm{n}^{\circ} 2$ (LO of the calcareous nannofossil Quadrum trifidum) is older than the former;

$\mathrm{n}^{\circ} 3$ to 6 concern 3 ammonites and 1 belemnite; these four biohorizons are very close; $\mathrm{n}^{\circ} 3$ (FO of Hoploscaphites constrictus) may be slightly younger than $\mathrm{n}^{\circ} 4$ (FO of Pachydiscus neubergicus); both are not much younger than ${ }^{\circ} 5$ (FO of Belemnella lanceolata which has been extensively used in NW Europe); criterion $\mathrm{n}^{\circ} 6$ (LO of Nostoceras hyatti) has been observed immediately below $\mathrm{n}^{\circ} 4$ in most outcrops but a short contemporaneity of these two ammonites is sometimes suggested (Küchler et al., 2001).

$\mathrm{n}^{\circ} 7$ (FO of Globotruncana falsostuarti) and $\mathrm{n}^{\circ} 8$ (FO of $N$. hyatti) are older than the group above; Ward and Kennedy (1993) quote $n^{\circ} 8$ younger than $\mathrm{n}^{\circ} 7$ but the reverse is observed at Tercis.

$\mathrm{n}^{\circ} 9$ (LO of Radotruncana calcarata) is the oldest biohorizon. According to the data from Tercis the LO of R. calcarata would 
lie in beds deposited about 2 Ma before the now preferred boundary); this criterion was widely used for locating the CampanianMaastrichtian boundary in the Tethyan Realm; this taxon is easy to recognise, and its palaeogeographic distribution between $35^{\circ}$ North and 40 to $50^{\circ}$ South is wide (Odin, 2001, chapter F2).

In short, two main biohorizons ( $\mathrm{n}^{\circ} 9$ and $\mathrm{n}^{\circ}$ ) were commonly used in two distinct palaeobiogeographical areas (Tethyan and Boreal Domains respectively). For this reason, they have never been observed in direct relationship and this will probably never occur. They represent horizons separated by about $2.5 \mathrm{Ma}$ (Odin and Amorosi, 2001). For a precise definition of the Campanian-Maastrichtian boundary, it was thus necessary to decide where the boundary level should be placed. The results of the vote by the Maastrichtian Working Group (Odin, 1996) indicated an agreement for a median level: the FO of Pachydiscus neubergicus is the preferred guide-event to approach the level (86.5\% majority).

The newly established concept of guide-event (Odin, 1996; 2001) considers that a single biohorizon is not unequivocal enough (potential problems in taxonomic definition, local records, lateral reproducibility) for a boundary to depend on this marker alone: a combination based on the location of several nearby biohorizons more securely represents a chronologically significant level. Thus a combination of criteria depends on several marker horizons located in beds deposited near that of the guide-event; this original procedure for locating the global stratotype level and point has been approved by the MWG (62.2\% majority).

Literature shows that few outcrops continuously record the interval covered by biohorizons 1 to 9 quoted above. The seemingly best outcrop near Dax showed more promising than really known. This paper gives summarised information on this outcrop and on some others reviewed for comparison during the last 8 years. A special volume (Odin, 2001) provides general and geological information on the Geological Site established at Tercis and considers this new knowledge in comparison to other outcrops. The new GSSP was successively approved by the MWG (proposal September 1999), the Subcommission on Cretaceous Stratigraphy (proposal June 2000), the International Commission on Stratigraphy (proposal December 2000) and ratified by IUGS (February 2001).

\section{The geological site at Tercis les Bains}

The most recent studies on the Geological Site of Tercis before the action of the MWG were undertaken according to a section studied about 20 years ago (Hancock et al., 1993; Simmons et al., 1996; Ward and Orr, 1997). Since then, the hill was deeply quarried and the look of the lithological succession changed significantly, so that it happened that the succession previously described by Hancock et al. (1993) could not be unequivocally recognised today. A major reason is the generally homogeneous character of the deposits, another one is the difficulty to measure the actual thicknesses in a vertically bedded outcrop which is not perpendicular to the beds.

Major results of these previous works include the discovery of the presence of both macro- and microfossils and the feeling that the succession was continuous across the stage boundary, justifying heavy involvement of the stratigraphers' community. A precise description was achieved and published (Odin \& Odin, 1994) and fixed marks painted in the quarry at approximately $1 \mathrm{~m}$-thick intervals later called "levels".
An extensive, self-consistent, and precise sample collection began and has been constantly supplemented for the following years.

\section{Geography, palaeogeography, geology, outcrop}

The outcrop is situated $8 \mathrm{~km}$ from Dax in the Landes (SW France) between the Basque Region to the south and the Charente province to the north (Figure 1). The area is located in a small basin (the Aturian Basin) north of the Pyrenees (Figure 2), which belongs to the Tethyan Realm and is an appendix of the North Atlantic Ocean. This location was favourable to biological exchanges between the cold temperate realm (Charente, Maastricht-Limburg, Kronsmoor-North Germany, Norfolk-England and Vistula Valley-Poland, see C, M, K, N, and W resp. in Figure 1) and the Tethyan Realm (Spanish Navarra, Gubbio in the Italian Apennines, El Kef and Kalaat Senan area in Tunisia), the fauna of which is present in this Aturian Basin. Contemporaneous (Campanian and Maastrichtian) lacustrine and continental deposits are locally interfingered with marine ones immediately to the East of this basin. These facies are known to the east of Tercis from the Comminges and Corbières and farther east from Provence. This set of outcrops is rich in reptilian-bearing sites still under study (Laurent et al., 2001). Connection of marine and continental stratigraphy is of superior interest for the designation of a reference section in this context.

The quarry is situated on the left bank of the Adour River (Figure 1). The outcrop is part of the east-west ridge of Tercis-Angoumé. Mesozoic strata outcrop vertically on the northern flank of this anticline which is partially of diapiric origin; in the middle, there are upper Triassic deposits of Germanic facies (Figure 3). The quarry comprises five formerly worked (by Ciments Calcia) "platforms", each 5 to $7 \mathrm{~m}$ high, opening westwards between the south and north walls, about $100 \mathrm{~m}$ apart. These platforms (Figure 4) allow repeated observations of the series. Across the Campanian-Maastrichtian transition, the chronostratigraphic extent of the site includes about

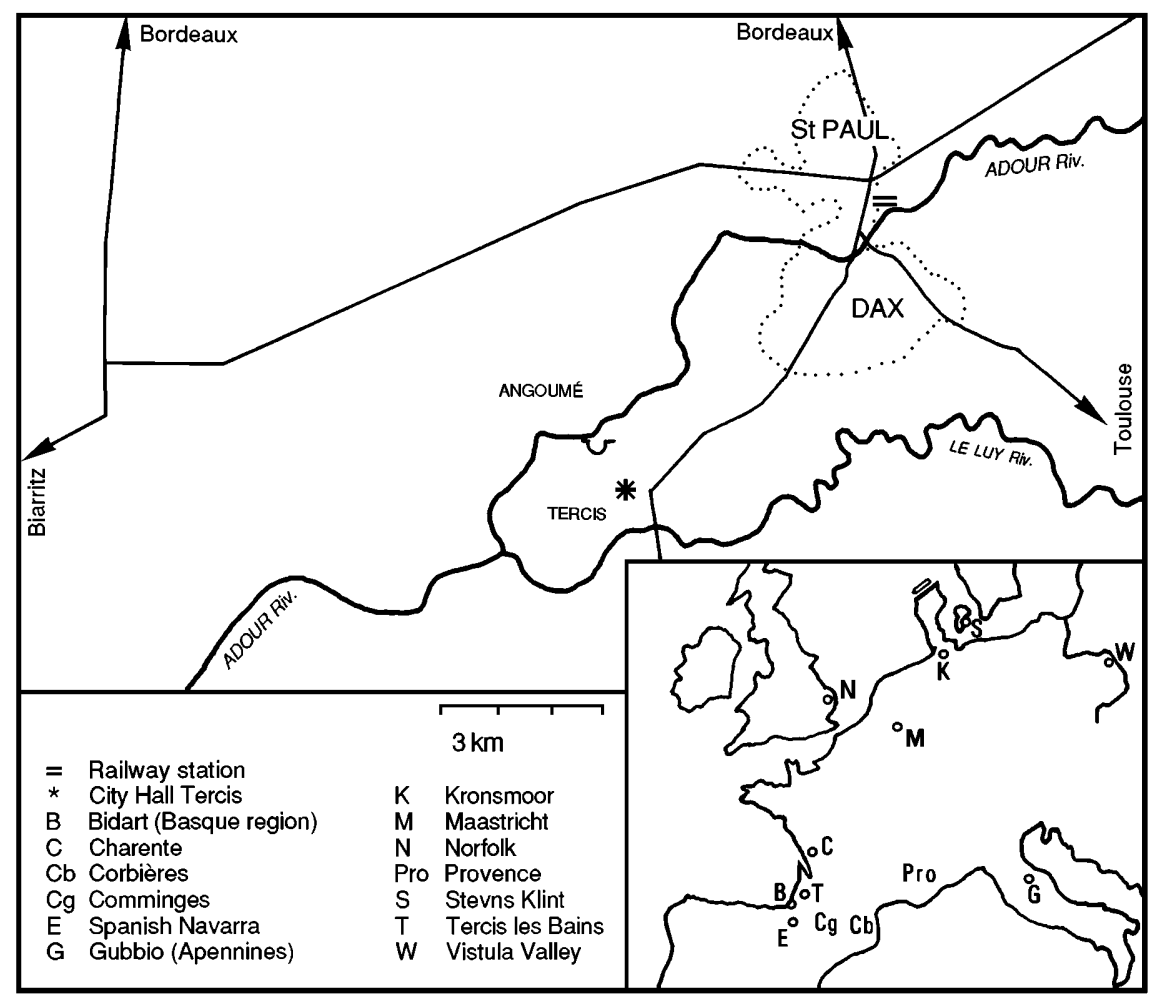

Figure 1 Location of the geological site (20 minutes by car from Dax railway station or the Bordeaux-Biarritz motorway). Other important geological sites such as the historical stratotypes of the Campanian and of the Maastrichtian stages, the suggested auxiliary stratotype sections (Gubbio, Kronsmoor) and other well-known sections are shown in the inset. 


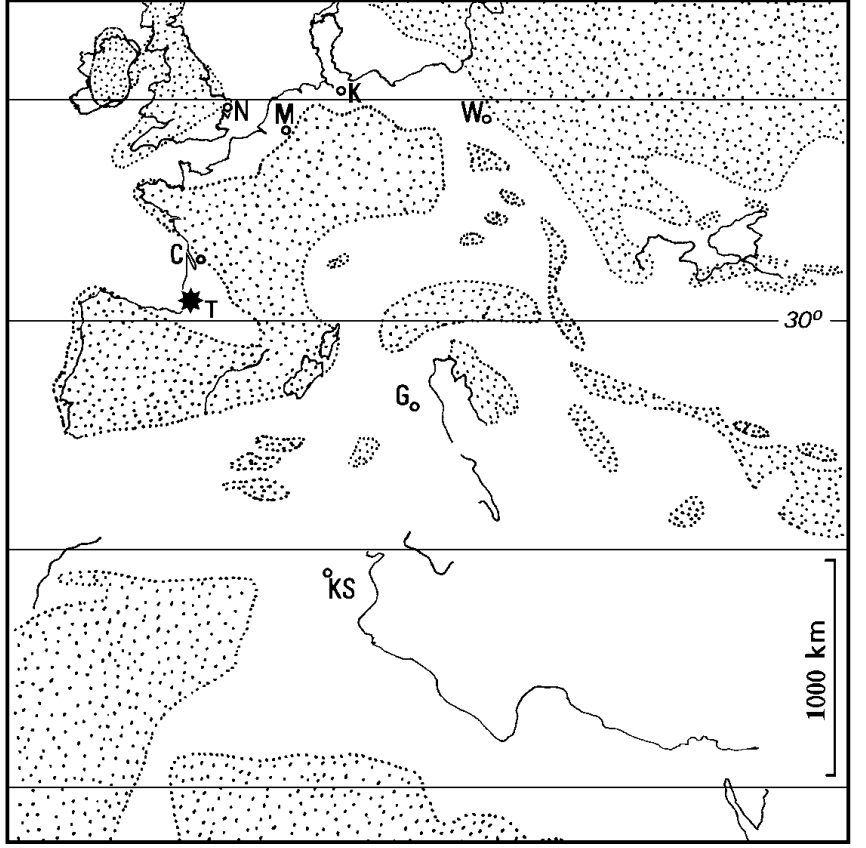

Figure 2 Schematic palaeogeographic reconstruction of the west European platform about 69 Ma ago (simplified from Bilotte et al., 2001). The Tethyan Tercis area (star) is located in an appendix (the Aturian Basin) of the NE Atlantic Ocean. Exchanges with the Boreal Realm to the north were possible. Exchanges with North America are also possible and occurred along the oceanic streams. Dotted area: emerged land; letters as in inset of Figure 1 but KS: Kalaat Senan (Tunisia).

half of the Campanian stage below, the whole Maastrichtian, and the basal portion of the Palaeogene.

Access to the site is possible under legal restriction insuring protection. Working of the quarry stopped in 1993. For the security of geologists and future educational field trips, a replanning of the site has been undertaken in cooperation with the undersigned Maas-

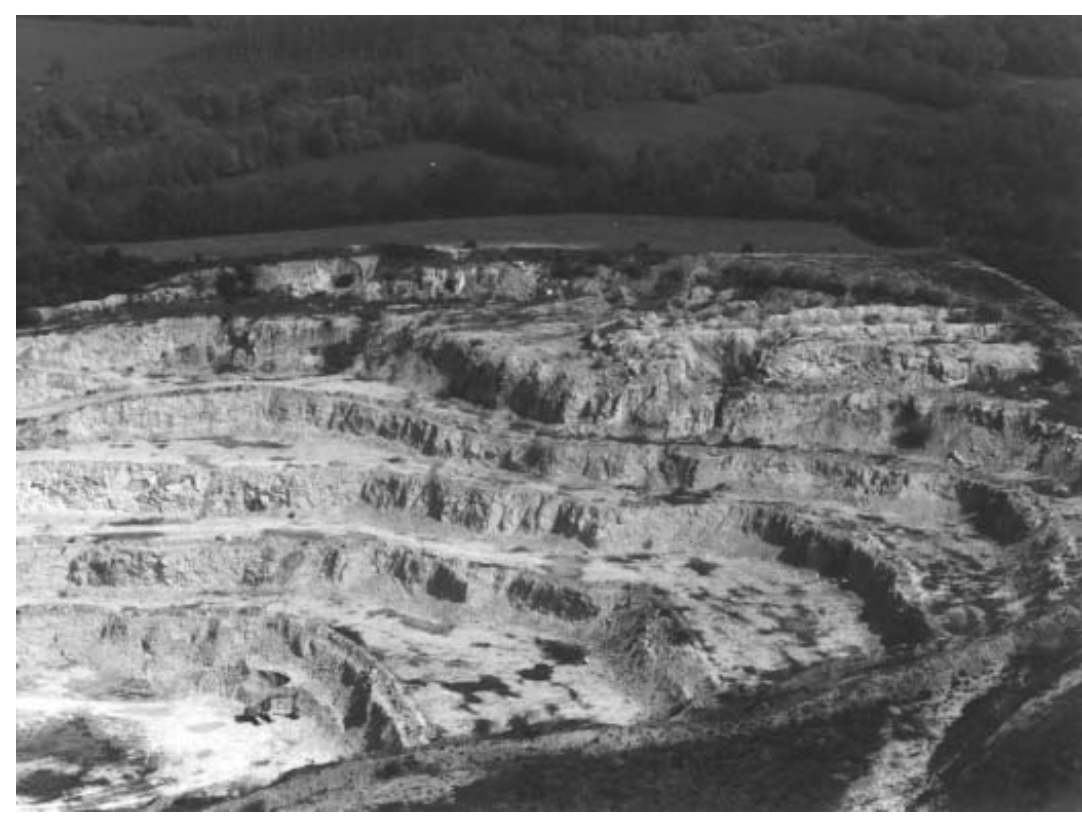

Figure 4 Aerial view of the eastern end of the quarry (east to the right). The Adour River can be seen to the top of the picture. Old levels are at the bottom and the young ones at the top. The vertical beds can be observed on 6 platforms (view taken in 1997 before rearrangement, scale given by the quarry scraper, bottom left).

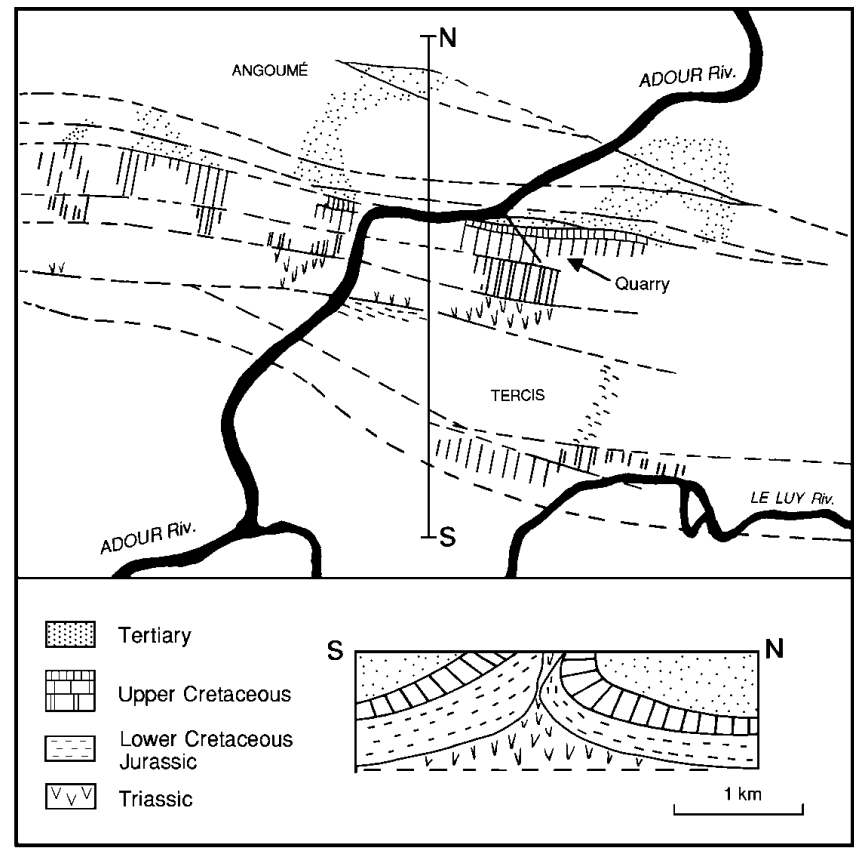

Figure 3 Simplified geology of the Tercis area. NS: an about 4 km-thick schematic North-South section. The Upper Cretaceous is subdivided into 1-Cenomanian to Santonian, 2-Campanian, and 3-Maastrichtian.

trichtian Working Group leader, aiming at preserving and improving accessibility. The past owners (Ciments Français, presently Ciments Calcia) agreed to entrust the site, more than 30 ha large, to the village authority which accepted to keep it for preservation of its geological interest (September 1997). Its primary geological interest is supplemented by significant biological and archaeological interests which are considered in several chapters of the monograph (Odin, 2001).

The strata were placed in a vertical position during the Pyrenean orogeny. Tectonical field study allowed to locate and analyse the geometric relationships between several tectonical blocks (Rocher, 2001) and thus to draw a precise (at the $10 \mathrm{~cm}$ scale) connection between the different profiles sampled, with the help of sedimentological features. No fault affects the main section to the east of the quarry but previously unknown faults (throw up to 7 metres) affect the series laterally.

\section{Lithostratigraphy, depositional rate, rhythm, sequence, chemo-physical stratigraphy}

The section in the quarry is $165 \mathrm{~m}$ thick (P in Figure 5). Another $60 \mathrm{~m}$-thick section is visible around the north entrance of the quarry (E outcrop in Figure 5). Older strata are visible to the south. Younger strata are visible to the north of the quarry in small exposures up to the "Mur de Bédat", a silicified bed precisely located immediately above the Cretaceous-Palaeogene boundary (Outcrops B).

The synthetic section is about $310 \mathrm{~m}$ thick. It has been subdivided into the Lacave, Hontarède, d'Avezac, Les Vignes, and Bédat Units from bottom to top. The Lacave Unit displays a shallow rudist-bearing facies for most of its thickness, the age of which is Turonian and Coniacian according to echinoids and brachiopods. The top two metres of this Unit is mid Campanian in age according to starfish remains (asteroids). A blade of Cenomanian oyster-bearing clays exists below. The Hontarède Unit is essentially azoic 


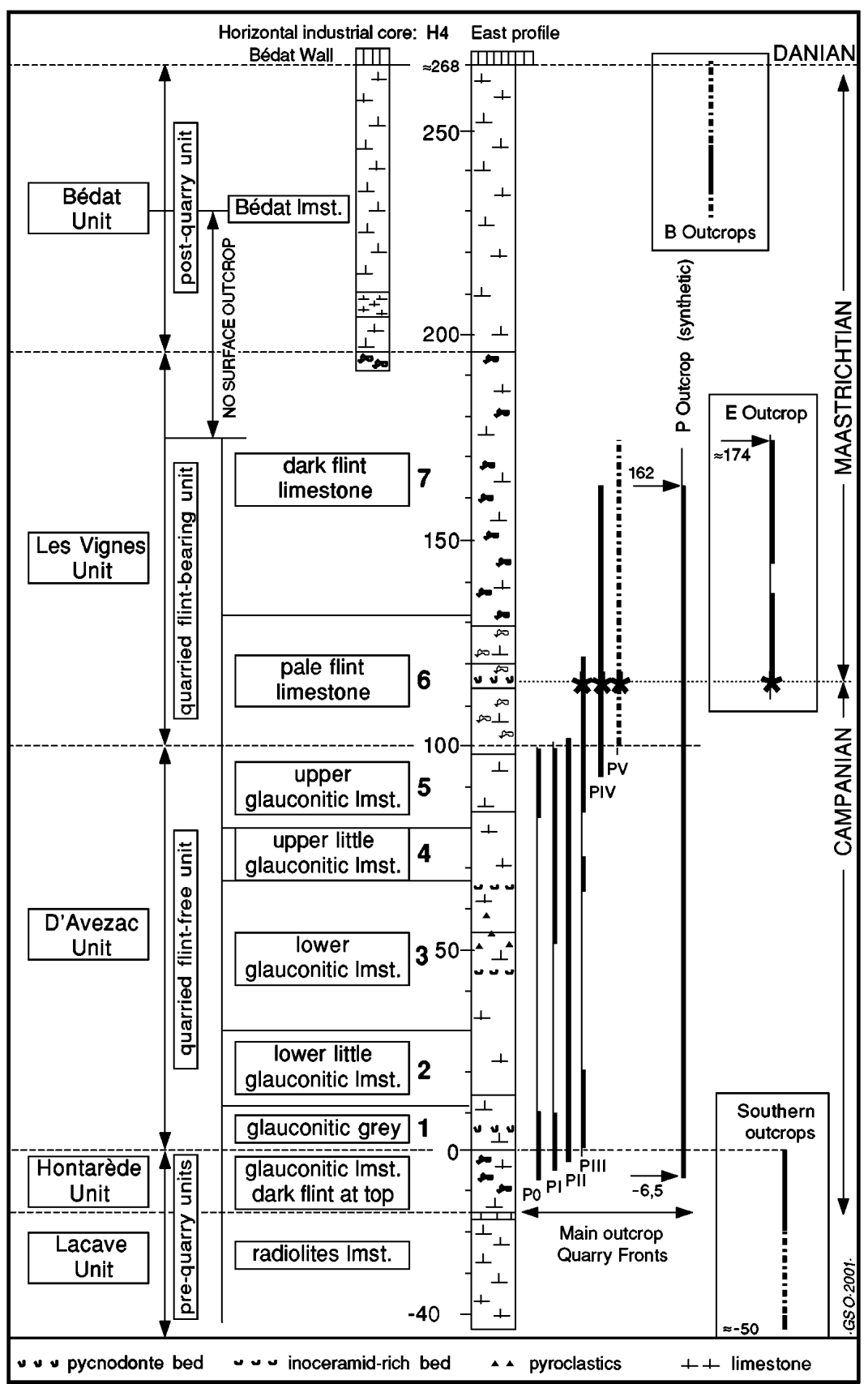

Figure 5 Synthetic profile of the Late Cretaceous deposits cropping out in the geological site at Tercis. The Campanian-Maastrichtian boundary interval is exposed in sections PIII, PIV, PV and E.

but for its top which seems in depositional continuity with the upper Campanian deposits of the quarry. The deposits in the quarry have been subdivided into the d'Avezac Unit below (without flint) and the Les Vignes Unit above (with flint). The d'Avezac/Les Vignes limit is about similar to the limit between lithological units $\mathrm{J}$ and $\mathrm{K}$ of Hancock et al. (1993). The d'Avezac Unit can be subdivided into five subunits according to the presence of glaucony, a key sedimentological feature in this homogeneous succession; its thickness is about 100 metres (86 $\mathrm{m}$ according to Hancock et al., 1993; $99 \mathrm{~m}$ in Simmons et al., 1996). The Les Vignes Unit has been subdivided into a pale flint-bearing (below) and a dark flint-bearing subunit above.

Our pale flint-bearing subunit is about $31 \mathrm{~m}$ thick, in agreement with that of Hancock et al. (1993). A distinct pycnodonte-rich (comparatively deep-water oysters) horizon is located near the stage boundary ( $1 \mathrm{~m}$ above according to "the ammonite scale"; $2.5 \mathrm{~m}$ above according to the "planktic scale" of Christensen et al., 2000; $2.1 \mathrm{~m}$ above according to our description). However, the section of Hancock et al. (1993) shows this pycnodonte-rich horizon about $7 \mathrm{~m}$ below the top of the pale flint-bearing subunit while our description shows it about $14 \mathrm{~m}$ below.

Several profiles were measured in the quarry around the Campanian-Maastrichtian transition and numbers were painted about every metre (Odin and Odin, 1994; Odin, 1996). The homogeneous pithonellid-bearing limestone (95\% carbonate) of the quarried portion of the section characterises an open marine environment, the depositional depth of which probably fluctuated between $50 \mathrm{~m}$ and $200 \mathrm{~m}$. The main lithological variations are related to the amount of glaucony and the development of chert (pale or dark flint) as used for lithological subdivision.

There is an apparent rhythm of the concretions of chert; another rhythm has been found with a similar (metric) period in alternate clay contents in the flintfree limestone of the d'Avezac Unit. Chert rhythm has been interpreted of climatic origin in the Maastrichtian of Limburg (Zijlstra, 1994). In our quarry, several approaches including biozone and stage duration estimates have led to suggest a constant depositional rate of $25 \mathrm{~m} / \mathrm{Ma}$, which implies that the metric rhythm represents about 40 ka (Odin and Amorosi, 2001). With this interpretation, and in general agreement with estimates in other sections, the succession in the quarry would include the record of more than 7 Ma of deposition, 5 Ma below, and 2 Ma above the stage boundary.

Physico-chemical investigation has been undertaken for trace elements, stable isotopes, strontium isotopes, and magnetostratigraphy with promising results. Direct magnetostratigraphic data suggest that the first half of the deposits in the quarry pertains to magnetozone $33 \mathrm{~N}$. Thanks to the diversified biostratigraphic characterisation, data from other sections could be precisely tied to the Tercis section (see Figure 8). Indirect magnetostratigraphy could then be provided; the main section would correspond to the sequence between magnetozone $33 \mathrm{~N}$ (top half) for the Campanian d'Avezac Unit and 31R (base) for the Maastrichtian dark-flint-bearing subunit of the Les Vignes Unit (Lewy and Odin, 2001).

Trace element investigation (Barchi et al., 1994) contributed to document a sequence stratigraphic interpretation. The glaucony content and mineralogy deliver other useful features (Amorosi, 1995) which allowed the identification of five depositional sequences (TS 1 to TS 5 in Figure 10) in the upper Campanian and lower Maastrichtian (Odin and Amorosi, 2001).

\section{Biostratigraphy}

Biostratigraphy finds a remarkable field of application in our geological site. More than 2,600 specimens of macrofossils have been collected and submitted to palaeontologists. Microfossils were investigated using washed residues, thin sections, and several techniques of rock dissolution. 464 genera and 932 species or subspecies are quoted in the monograph for specimens collected before June 1999. Four fossil groups (calcareous nannofossils, sporomorphsmainly angiosperms-, dinoflagellate cysts and planktonic foraminifera) comprise more than 100 species each. This variety at Tercis is comparable to that of the historical stratotype of the Maastrichtian in Limburg which has delivered about 1,000 species after a century of study. Major fossil groups have been studied by several experts or groups of experts and the results are exposed indepen- 


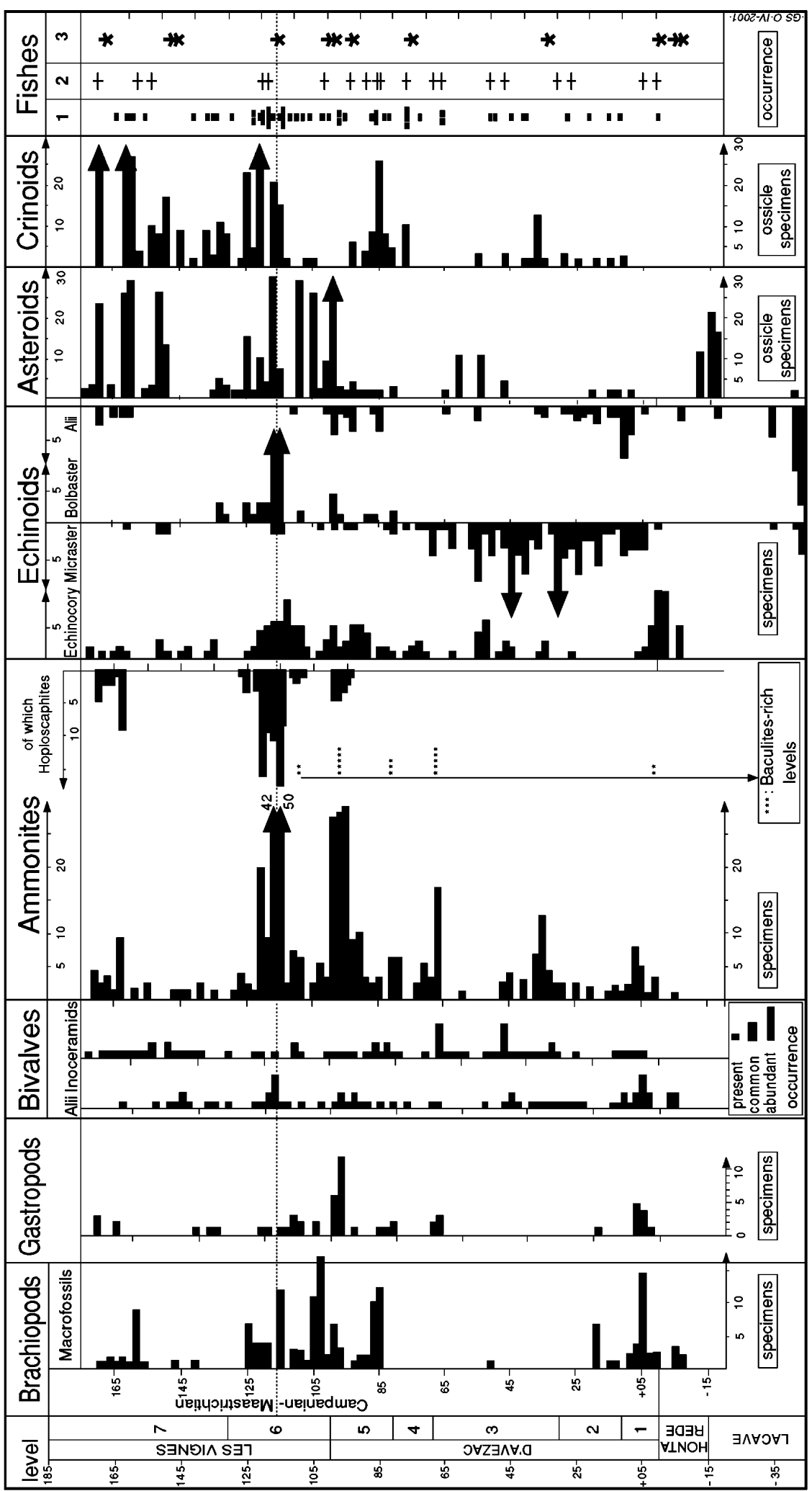

dently in the monograph before a synthetic view is proposed for each group. This cooperative approach allows an experimental uncertainty in the location of the biohorizons to be documented.

Figure 6 shows the occurrence of macrofauna. The genus Baculites is shown in a separate column for these ammonites have been observed but not collected. In the column inoceramids, "abundant" means that it is possible to collect as many specimens as wanted. Sponges, corals, worms, bryozoans, nautiloids are also present and may locally be common. Nine macrofossil groups are documented in detail in the monograph.

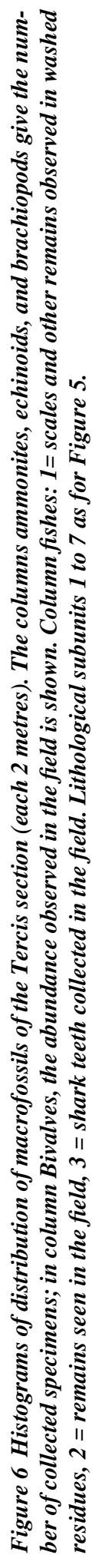

The microfauna is diversified around the stage transition (Figure 7). The scarcity of sporomorphs will make correlation with continental deposits difficult before further investigation. Most studies achieved up to now were not exhaustive and progress is expected in the near future. Eight microfossil groups (pollen, dinoflagellates, benthic and planktonic foraminifera, microbrachiopods, ostracodes, ophiuroids, holothurians) are documented in the monograph, most of them studied independently by several (up to four) experts or groups of experts.

\section{Definition of the stage boundary}

When biostratigraphy is the most powerful correlation tool, as it is the case at Tercis, the best stage boundary should be located where the widest change is located. Two main biological changes are documented around levels 97.5 and 115.5 according to calcareous nannofossils, dinoflagellate cysts, benthic foraminifera, planktonic foraminifera, ammonites and inoceramids.

The Cretaceous community has expressed its preference for the time of appearance of Pachydiscus neubergicus as the guide-event. This biohorizon is located within the youngest interval quoted above. The FO of $P$. neubergicus has been documented by fossils identified by four experts (W.A. Cobban, P. Courville, W.J. Kennedy, P.D. Ward) at or below level 116.1 (biohorizon 1, Figure 8). Kennedy and Summesberger (1986) suggest that $P$. neubergicus originates from a paedomorphic evolution of P. perfidus; transitional forms exist at Tercis between levels 115.2 and 117.5, which allows to document a transition interval.

Two other ammonite biohorizons are of interest. Biohorizon 2 is the LO of Nostoceras hyatti (with the allied taxon $N$. sp.2 of Küchler, in Küchler and Odin, 2001) at or above level 114.1. Biohorizon 3 is the FO of Diplomoceras cylindraceum at or below level $111 \pm 3$. The latter taxon is easy to identify and it is present worldwide in Europe, North and South America, India, Africa, India, Australia.

Dinoflagellate cysts provide an excellent biostratigraphic record in the type section (Antonescu et al., 2001), and three biohorizons have been selected bracketing biohorizon 1. Biohorizon 4 is the LO of Corradinisphaeridium horridum at level $112.4 \pm 2.4$ and the taxon is easy to identify; biohorizon 5 is the LO of Raetiaedinium truncigerum (conspecific with $R$. evittigratium of other authors), a form which is not so difficult to identify and disappears at level $118.6 \pm 3.8$. The species of the genus Samlandia are more difficult to 


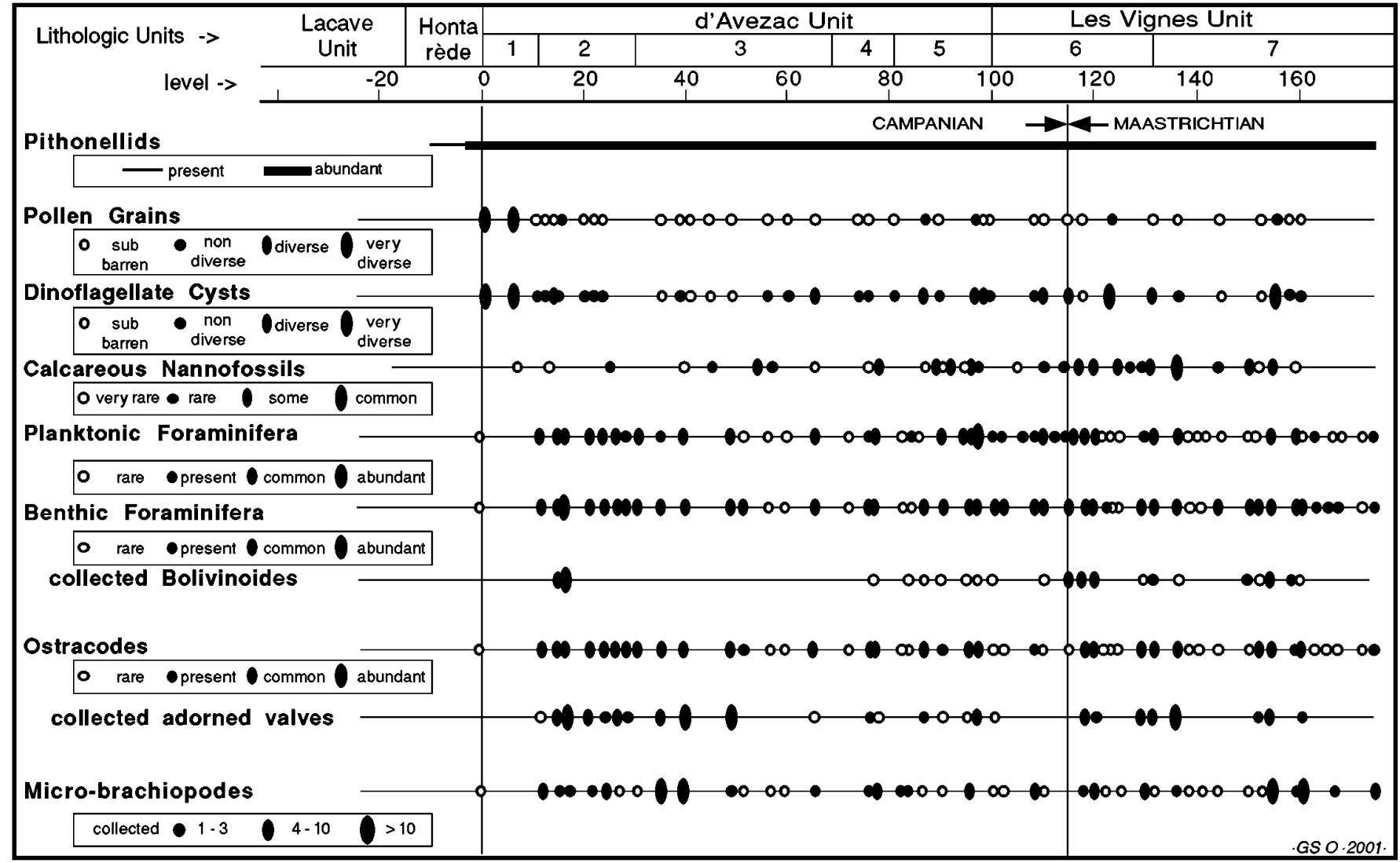

Figure 7 Distribution of microfossils along the main section bracketing the Campanian-Maastrichtian boundary interval. Lithologic subunits 1 to 7 as for Figure 7. In addition, micro remains of ophiuroids, holothurians, and fishes (teeth and scales) have been considered.

identify and the apparently contemporaneous LOs of two of them give biohorizon 6 (at or above level 122.4).

As for the planktonic foraminifera, two biohorizons have been documented in the vicinity of biohorizon 1 by J. Arz, M. Caron, J. Ion, E. Molina. Biohorizons 7 and 8 are the FO of Contusotruncana contusa and the FO of Rugoglobigerina scotti as interpreted by the authors in the Tercis section. The latter is a fossil which is easy to identify without doubt although primitive specimens might differ from typical forms at the bottom of the range. These taxa pertain to

\begin{tabular}{|c|c|c|}
\hline Fossil group & level & $\neq \mathbf{k a}$ \\
\hline \multicolumn{3}{|l|}{ Ammonites } \\
\hline 1- FO Pachydiscus neubergicus & $\leq 116,1$ & $\approx 35$ \\
\hline 2- LO Nostoceras hyatti and allied forms & $\geq 114,1$ & $\approx 45$ \\
\hline 3- FO Didymoceras cylindraceum & $\leq 111 \pm 3$ & $\approx 165$ \\
\hline \multicolumn{3}{|l|}{ Dinoflagellate cysts } \\
\hline 4- LO Corradinisphaeridium horridum & $112,4 \pm 2,4$ & $\approx 110$ \\
\hline 5- LO Raetiaedinium truncigerum $(\approx$ R. evittigratium $)$ & $118,6 \pm 3,8$ & $\approx 135$ \\
\hline 6- LOs Samlandia mayii \& S. carnarvonensis & $>122,4$ & $\approx 300$ \\
\hline \multicolumn{3}{|l|}{ Planktonic foraminifera } \\
\hline 7- FO Contusotruncana contusa & $116,5 \pm 0,3$ & $\approx 50$ \\
\hline 8- FO Rugoglobigerina scotti & $116,2 \pm 0,5$ & $\approx 40$ \\
\hline \multicolumn{3}{|l|}{ Benthic foraminifera } \\
\hline 9- $\quad$ FO Bolivinoides 5 lobes $>4$ on last chamber & $107,4 \pm 7,4$ & $\approx 310$ \\
\hline 10- LOGavelinella clementiana & $115,5 \pm 0,7$ & $\approx 12$ \\
\hline \multicolumn{3}{|l|}{ Inoceramids } \\
\hline 11- FO genus Trochoceramus & $\leq 97,7$ & $\approx 700$ \\
\hline $\begin{array}{l}\text { Calcareous nannofossils } \\
\text { 12- LO Ouadrum trifidum }\end{array}$ & $134.2 \pm 2.7$ & $\approx 750$ \\
\hline Arithr & 11 & \\
\hline
\end{tabular}

Figure 8 Criteria selected for documenting the biological change containing the guide-event (after Odin, 2001). The age difference (sedimentary thickness estimate in $\mathrm{ka} \pm 50 \%$ ) between the GSSP level and the biohorizon is given for information. two families which lived in slightly different environments and deposits from both environments can thus be correlated.

Two benthic foraminiferal biohorizons were selected near biohorizon 1 (Tronchetti et al., 2001). Biohorizon 9 is the LO of Gavelinella clementiana at level 115.5. Biohorizon 10 is a change in the evolutionary lineage of the genus Bolivinoides, established following a statistic study; the resulting information is less precise (level $107.4 \pm 7.4$ ) but its evolutionary nature is quite certain.

Two important fossil groups, inoceramids and calcareous nannofossils, were absent from this selection. It appeared important that they should contribute and the following two stratigraphic signals bracketing biohorizon 1 have been selected. The genus Trochoceramus is an inoceramid taxon which can be identified in the field. Its FO (biohorizon 11) is at or below level 97.7. Walaszczyk et al. (1996) supported the idea that the inception of "this genus lies in the topmost Campanian or even within the Maastrichtian"; it is older than the stage boundary at Tercis and this represents chronologically significant information. The taxon Quadrum trifidum can be identified without difficulty; it plays an important role in biozonation; its $\mathrm{LO}$ (biohorizon 12) is Maastrichtian in age at level 134.2 \pm 2.7 (Gardin et al., 2001b).

The arithmetic mean of the twelve biohorizons' levels is 115.2. If one ignores the last two criteria located far from the boundary, the resulting arithmetic mean level would not be different by more than $\pm 1 \mathrm{dm}$ which represents a duration of deposition of less than $10 \mathrm{ka}$. Therefore, level 115.2 is the recommended level where to place the GSSP for the stage boundary. No $P$. neubergicus specimen is known below this level near 


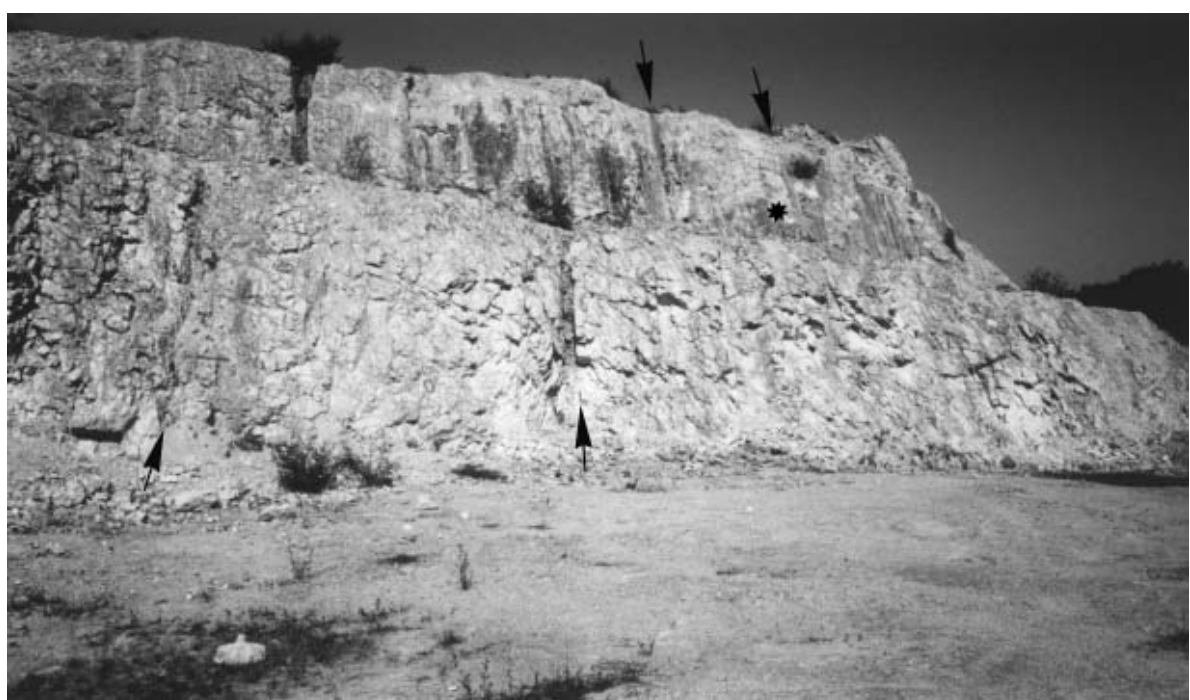

Figure 9 The Campanian-Maastrichtian boundary at Tercis. Vertical bedding, Maastrichtian to the left, Campanian to the right. Bed cuts at levels 114 and 120 are shown on top of platform IV and bottom of platform III. The GSSP (star on platform IV) is about $1.2 \mathrm{~m}$ above (to the left of) level 114.

Dax; the nearest one is not younger by more than 20 to $40 \mathrm{ka}$ than the time of deposition of the recommended level.

The MWG is aware that selecting many criteria for locating a single level enhances the probability that one or several of these criteria are not evolutionary events; but a combination of biohorizons results in much higher a probability for the obtained level to be the mark of an evolutionary phenomenon, an acceleration of evolution, characterising the stage boundary.

In the Upper Cretaceous, the Campanian-Maastrichtian stage boundary is defined at level 115.2 on platform IV of the geological site at Tercis les Bains (Landes, France). Following IUGS ratification in February 2001, the GSSP has been fixed in the section as shown in Figure 9.

\section{Interest of a definition at Tercis}

Tercis is palaeogeographically situated at the northernmost end of the Tethyan Realm and the deposits contain typical Tethyan fauna and cosmopolitan taxa also present more to the North.

The outcrop is located to the West of Europe with an opening toward the Atlantic Ocean, which simplifies correlation with North America. The deposits contain fossils similar to those of North America, including planktonic foraminifera and macrofossils such as ammonites and inoceramids (I. Walaszczyk, personal communication, work in preparation).

Sedimentologically, the deposits at Tercis indicate an external platform facies at the crossing of the platform (with echinoderms, ammonites and inoceramids, some shallow dinoflagellates and benthic foraminifera) and of the open ocean (with calcareous nannofossils, planktonic foraminifera, and open sea dinoflagellates).

Although fully oceanic at the time of the Campanian-Maastrichtian boundary, Tercis was not far from land and shallow basins where lacustrine and continental deposits occurred. The vicinity of land has been nicely exemplified by the discovery of typical continental remains (burnt plants and a dinosaur) which were floated into the series. This proximity also allowed pollen to be fossilised in the same deposits.

A major goal of the MWG was to bring the previously poorly known Tercis section together with the best-known sections in the world. Interfingering of up-to-now independent biostratigraphic scales has been realised for the first time during this work. Finally, recent studies have widely confirmed the interest of the outcrop announced by previous research workers for the interval between 77 and $70 \mathrm{Ma}$. Additional studies would still increase the interest of this interval. Besides, the deposits located above, buried between 70 and 65 Ma ago, could be studied in the future in the portion of the geological site where outcrops can be created.

\section{Correlation with other areas}

Correlation with other areas comprises: 1-correlation to historical stratotypes; this point must answer the essential condition of consistency between the new GSSP and previous definition; 2-correlation with other well known sections; this point will allow better or additional documentation of stratigraphical tools weakly recorded in the GSSP; 3-potential correlation with unknown sections.

The historical stratotypes have been reviewed in the monographs (Jagt, 2001; Neumann and Odin, 2001). Correlation by ammonites, calcareous nannofossils, dinoflagellate cysts and asteroids shows that the newly established boundary at Tercis is younger than the younger deposits of the historical stratotype of the Campanian Stage (Coquand, 1857). In the Champagne charentaise (see Charente in Figure 1 and 2) the Campanian of Coquand appears older than the FO of Nostoceras hyatti. Ammonites and dinoflagellate cysts indicate that the newly established boundary is located far below the oldest deposits of the historical stratotype of the Maastrichtian Stage of Dumont (1849) in Limburg. Therefore, the GSSP at Tercis is located in levels previously not attributed in the historical stratotypes and the new definition is consistent with the original ones.

Correlation with well known sections has been considered with regard to the boreal German section at Kronsmoor where belemnites are the endemic key fossils. Two indirect correlations through Poland (Vistula Valley) and Norfolk (England) can be suggested. Tercis and Poland are correlated using the LO of Nostoceras hyatti which is assumed to be below the FO of Belemnella lanceolata in that country. Tercis and Norfolk are correlated using echinoids ranges which suggest that the FO of $P$. neubergicus at Tercis would be contemporaneous ( \pm about $0.1 \mathrm{Ma}$ ) with the $\mathrm{FO}$ of $B$. lanceolata in Norfolk (Christensen et al., 2000). Dinoflagellate cysts confirm this correlation (Antonescu et al., 2001). Therefore, the FO of $B$. lanceolata can be used as a boreal proxy of the stage boundary defined at Tercis. The belemnite scale (see Figure 10) and strontium geochemical information known from N. Germany could thus be correlated with Tercis.

In the Tethyan Realm, correlation can be established with North Spain (Küchler et al., 2001), or with the Apennines (Gardin et al., 2001a). The latter correlation can be achieved in a number of points of the Tercis series using calcareous nannofossils, planktonic foraminifera and magnetic signals combined with short term sedimentary thickness interpolation through beds deposited at a reasonably constant depositional rate. The better known magnetostratigraphic record of the Apennines can thus be correlated with the Tercis succession.

Still in the Tethyan Realm, sections in Tunisia display some nostoceratid ammonites, inoceramids (Trochoceramus) and a diversified planktonic microfauna in the area of Kalaat Senan (Robaszynski et al., 2000). These sections can be correlated to Tercis and useful information derived from their comparison concerning the reproducibility of the biostratigraphical signals.

In North America, the bentonite-bearing succession of the Western Interior Province can be correlated with the Tercis succession via correlation including planktonic foraminifera, ammonites, inoceramids or magnetostratigraphic record. The geochronological 


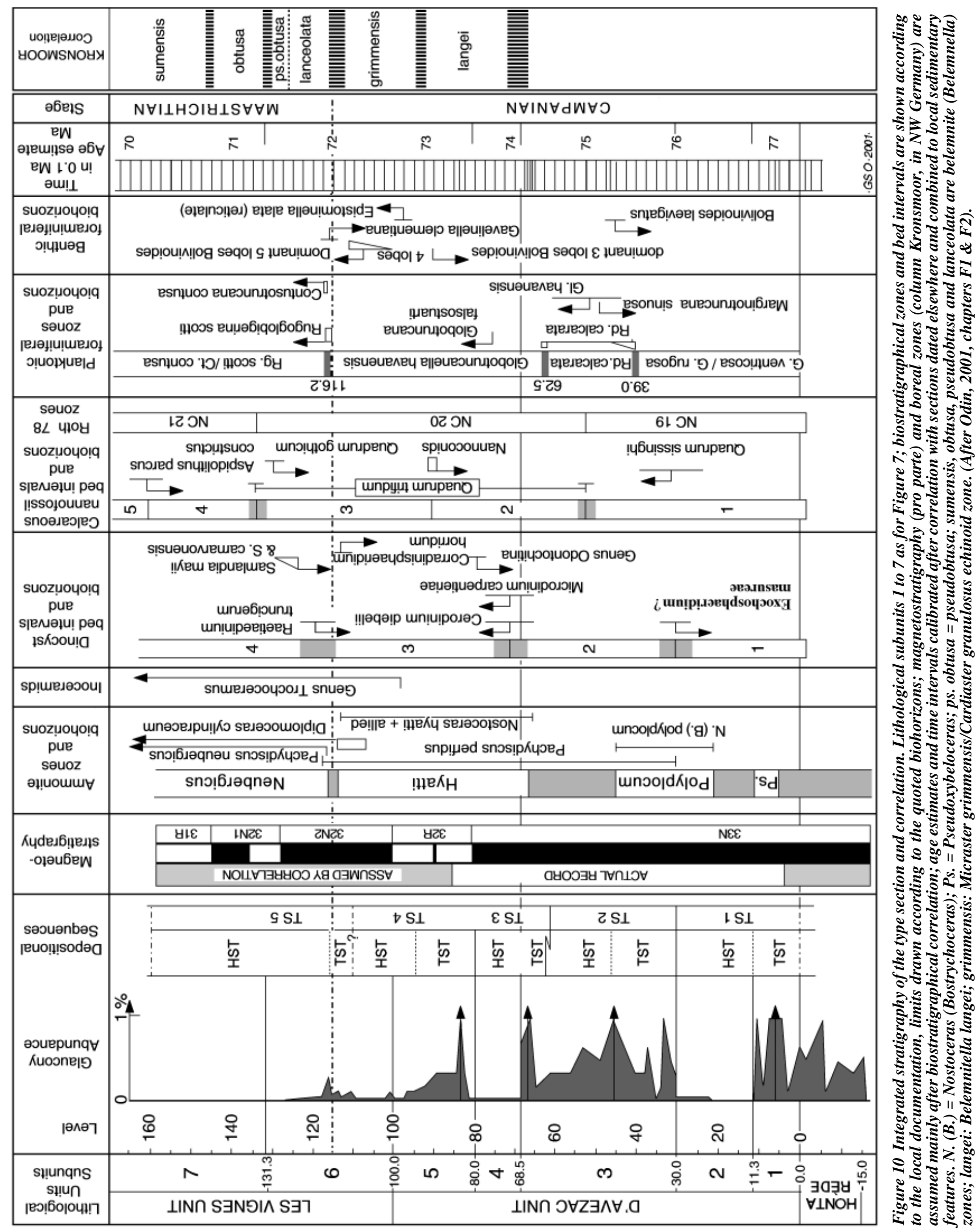


calibration of this American series indicates that the $\mathrm{LO}$ of $\mathrm{N}$. hyatti is in the interval 72.5-71.0 Ma.

\section{Concluding remarks}

For eight years, the quality of the succession at Tercis and its suitability as a global reference section have been enhanced by each new study. With this quality in mind, the opportunity was taken to develop a new approach for defining a stage boundary. Major stratigraphical tools have been studied in parallel by several experts, allowing objective and reproducible information to be obtained. As wide as possible a variety of stratigraphical tools has been considered, including the characterisation of 18 fossil groups following massive sampling. The stage boundary level has been drawn where the highest correlation potential had been determined by the combination of twelve biohorizons.

In addition, three concerns have been considered: 1-the search for correlation with the widest range of environment; 2-the search for a reasonably founded time dimension for the succession of events occurring near the boundary, and 3-the search for an estimate of the uncertainty on the results. Selected data are given in Figure 10.

Such a huge effort of the stratigraphers' community should result in a knowledge accessible to the widest public; in this context, the Geological Site at Tercis is now a candidate for an educational and possibly touristic use. Though not strictly geological, this concern may have its interest in the future of the research by providing some means for long term preservation of the reference section. Local and regional authorities have shown their interest in developing such a matter by granting the publication of the recently published monograph.

\section{Acknowledgements}

We thank A.V. Dhondt and P.F. Rawson for reviewing the previous versions of this paper. The present paper summarises information gathered by the 70 co-authors of the Maastrichtian Working Group. The leader of the Working Group deeply acknowledges the contributions by all experts. Permission for access to the quarry was repeatedly provided by the former owners (Ciments Calcia) who are thanked for their cooperation in the years 1992-1997. They also efficiently cooperated and assigned financial supports to pass on their property to the local authorities in order to establish a scientific and educational domain for long term preservation of this unique geological site.

\section{Glossary}

In this text, first occurrence and last occurrence (FO and LO) are observed biohorizons; they are considered as local bio-signals, the chronological significance of which, in terms of evolutionary appearance (inception) or evolutionary disappearance (extinction), is a hypothetical idealisation, the correctness and uncertainty of which should be documented.

\section{References}

Amorosi, A., 1995, Glaucony and sequence stratigraphy: a conceptual framework of distribution in siliciclastic sequences: J. Sedim. Research, v. 65, pp. 419-425

Antonescu, E., Foucher, J.-C., Odin, G.S., Schiøler, P., Siegl-Farkas, A., and Wilson, G. J., 2001, Dinoflagellate cysts in the Campanian-Maastrichtian succession of Tercis les Bains (Landes, France), a synthesis: in Odin, G.S., ed., 2001, see below, chapter C2d, pp. 266-279.

Barchi, P., Accarie, H., Bonnemaison, M., Galbrun, B., Odin, G.S. and Renard, M., 1994, Caractérisation géochimique de la limite Campanien-
Maastrichtien de la série de Tercis (Landes, France): Actes 1er Congrès français de Stratigraphie, Toulouse, 11-13 Sept. 1994; Strata, 6, p. 102.

Bilotte, M., Odin, G.S., and Vrielynck, B., 2001, Geology and Late Cretaceous palaeogeography of the geological site at Tercis les Bains (Landes, France): in G.S. Odin, G.S., ed., 2001, see below, chapter A4, pp. 47-59.

Birkelund, T., Hancock, J.M., Hart, M.B., Rawson, P.F., Remane, J., Robaszynski, F., Schmid F., and Surlyk, F., 1984, Cretaceous stage boundaries: Bull. geol. Soc. Denmark, v. 33, pp. 3-20.

Christensen, W.K., Hancock, J.M., Peake, N. and Kennedy, W.J., 2000, The base of the Maastrichtian: Bull. geol. Soc. Denm., v. 47, pp. 81-85.

Gardin, S., Del Panta, F., Monechi S., and Pozzi, M., 2001a, A Tethyan reference record for the Campanian and Maastrichtian stages: the Bottaccione section (Central Italy); review of data and new calcareous nannofossil results: in Odin, G.S., ed., 2001, see below, chapter E4, nnn-nnn.

Gardin, S., Odin, G. S., Melinte, M., Monechi S., and von Salis, K., 2001b, Results of the cooperative study on the calcareous nannofossils across the Campanian-Maastrichtian boundary at Tercis les Bains (Landes, France): in Odin, G.S., ed., 2001, see below, chapter C3e, 311-328.

Hancock J.M., and Kennedy, W.J., 1993, The high Cretaceous ammonite fauna from Tercis, Landes, France: Bull. Inst. roy. Sciences nat. Belgique, v. 63, pp. 149-209.

Hancock J.M., Peake N. B., Burnett J., Dhondt, A. V., Kennedy, W. J. and Stokes, R. B., 1993, High Cretaceous biostratigraphy at Tercis, SW France: Bull. Inst. roy. Sciences nat. Belgique, v. 63, pp. 133-148.

Jagt, J.W.M., 2001, The historical stratotype of the Maastrichtian: a review: in Odin, G.S., ed., 2001, see below, chapter E2, pp. 747-759.

Kennedy, W.J., and Summesberger, H., 1986, Lower Maastrichtian ammonites from Neuberg, Steiermark, Austria. Beitr. Paläont. Österr., v. 12, pp. 181-242.

Küchler, T., Kutz A., and Wagreich M., 2001, The Campanian-Maastrichtian boundary in northern Spain (Navarra province): the Imiscoz and Erro sections: in Odin, G.S., ed., 2001, see below, chapter E3, pp. 759-782.

Küchler, T., and Odin, G.S., 2001, Upper Campanian-Maastrichtian ammonites (Nostoceratidae, Diplomoceratidae) from Tercis les Bains (Landes, France): in Odin, G.S., ed., 2001, see below, chapter D4e, pp. 529-558

Laurent, Y., Le Loeuff, J., Bilotte, M., Buffetaut, E. and Odin G.S., 2001. Campanian-Maastrichtian continental-marine connection in the Aquitaine-Pyrenees-Provence area (S France). D10, pp. 694-711.

Lewy, Z., and Odin, G.S., 2001, Magnetostratigraphy across the CampanianMaastrichtian boundary at Tercis les Bains in comparison with northern Germany, the Apennines (Central Italy) and North America; biostratigraphical and geochronological constraints: in Odin, G.S., ed., 2001, see below, chapter B2d, pp. 183-193.

Neumann, M., and Odin, G.S., 2001, Le stratotype historique du Campanien, définition, éléments de corrélation: in Odin, G.S., ed., 2001, see below, chapter E1, pp. 713-745.

Odin, G.S., compiler, 1995, Toward a GSSP for the Campanian-Maastrichtian boundary. Second International Symposium on Cretaceous Stage boundaries (Bruxelles 1995); abstracts: pp. 162-164.

Odin, G.S., 1996, Observations stratigraphiques sur le Maastrichtien. Arguments pour la localisation et la corrélation du Point Stratotype Global de la limite Campanien-Maastrichtien: Bull. Soc. géol. France, v. 167, pp 637-643.

Odin, G.S., editor, 2001, The Campanian-Maastrichtian stage boundary: characterisation at Tercis les Bains (France): correlation with Europe and other continents: IUGS Special Publication (monograph) Series, v. 36; Developments in Palaeontology and Stratigraphy Series, v. 19, Elsevier Sciences Publ. Amsterdam, 910 p. content online at: www.elsevier.com/locate/isbn/0-444-50647-0

Odin, G.S., and Amorosi, A., 2001, Interpretative reading of the CampanianMaastrichtian deposits at Tercis les Bains: sedimentary breaks, rhythms, accumulation rate, sequences: in Odin, G.S., ed., 2001, see above, chapter B1c, pp. 125-135.

Odin, G.S., and Odin, P., 1994, Première description d'une coupe dans la localité aturienne de Tercis (Landes): contribution à l'étude de la limite Campanien-Maastrichtien: Géol. France, v. 2, pp. 31-37.

Rawson, P.F., Dhondt, A.V., Hancock, J.M. and Kennedy, W.J., 1996, Proceedings "Second International Symposiom on Cretaceous Stage Boundaries" Brussels 8-16 September 1995. Bull. Inst. r. Sciences Naturelles de Belgique, v. 66, pp. 1-117.

Robaszynski, F., Gonzales Donoso, J.M., Linares, D., Amédro, F., Caron, M., Dupuis, C., Dhondt, A.V., and Gartner, S., 2001, Le Crétacé supérieur de la Région de Kalaat Senan, Tunisie centrale: Bull. Centres Rech. Explor.-prod. Elf-Aquitaine, 22, 359-490.

Rocher, M., 2001, The site at Tercis les Bains (Landes), stratotype of the Campanian-Maastrichtian limit: insights from tectonic studies: in Odin, G.S., ed., 2001, see above, chapter A6, pp. 71-86. 
Simmons, M. D., Williams, C.L., and Hancock, J.M., 1996, Planktonic foraminifera across the Campanian-Maastrichtian boundary at Tercis, SW France: Newsl. Stratigr., v. 34, pp. 65-80.

Tronchetti, G., Ion, J., and Odin, G.S., 2001, Benthic foraminiferal content of the Campanian-Maastrichtian geological site at Tercis les Bains (France); Synthesis: in Odin, G.S., ed., 2001, see above, chapter C4c, pp. 345-354.

Walaszczyk, I., Smirnov, J.P., and Tröger, K.-A., 1996, Trochoceramid bivalves (Inoceramidae) from the Lower Maastrichtian of Daghestan (Aimaki section, NE Caucasus) and south-central Poland: Acta geologica polonica, v. 46, pp. 141-164.
Ward, P.D., and Kennedy, W.J., 1993, Maastrichtian ammonites from the Biscay Region (France, Spain): Paleontological Society Memoir, v. 34, pp. 1-58.

Ward, P. D., and Orr, W., 1997, Campanian-Maastrichtian ammonite and planktonic foraminiferal biostratigraphy from Tercis, France: J. Paleont., v. 71, pp. 407-418.

Zijlstra, J.J.P., 1994, Sedimentology of the Late Cretaceous and early Tertiary chalk of NW Europe: C.I.P.-Gegevens Koninklijke Bibliotheek, Den Haag, 192 pp.
Gilles $S$. Odin is a member of the French Centre National de la Recherche Scientifique. He contributed to the knowledge of several aspects of geochronology, of sedimentology, and stratigraphy. His present involvements include geochronology of sedimentary deposits, stratigraphy of the Mesoand Cenozoic marine deposits, fundamental aspects of the definition of stages, and arrangement of a geological site for scientificleducational purpose. He is the current chairman of the Subcommission on Geochronology.

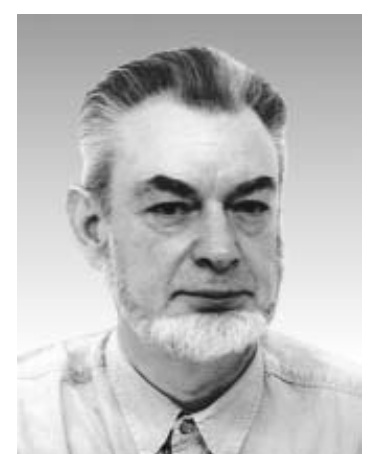

Michèle A. Lamaurelle, a former student of the Ecole Normale Supérieure de Fontenay aux Roses, is a scientist. She is currently a Professor of Chemistry. She has devoted personal interest in the development of the research on the geological site at Tercis and the reporting of the results which contributed to the achievement of the monograph gathering the results of the Maastrichtian Working Group of the Subcommission on Cretaceous Stratigraphy.
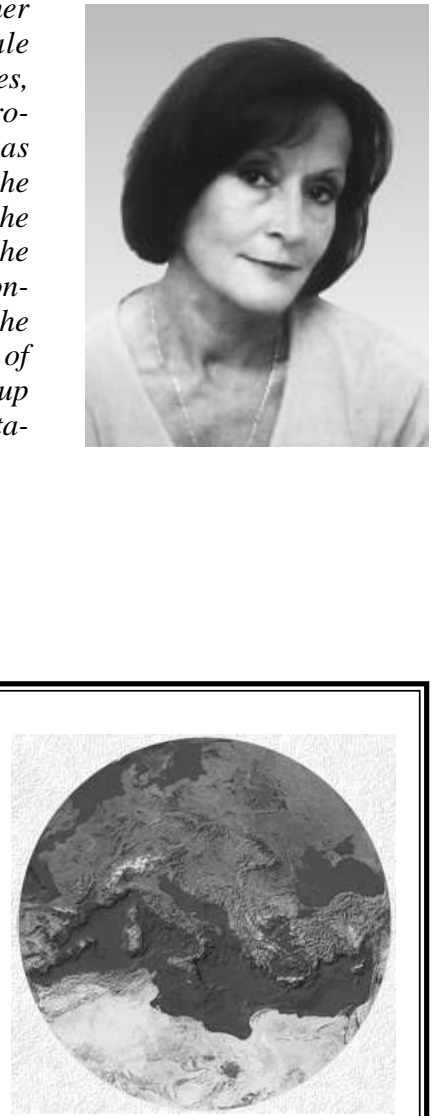

\section{Florence, Italy, 20-28 August 2004}

\section{In cooperation with and under the scientific sponsorship of the IUGS}

- President: Prof. Attilio Boriani, Milan University Secretary General: Prof. Ernesto Abbate, Florence University

- First Circular will be issued by April 2002. Persons desiring to receive the 1st Circular should send e-mail to: 32igc@32igc.org or visit the Congressweb sitewww.32igc.org.

- Communications:

\section{Chiara Manetti}

Università degli Studi di Firenze

Dipartimento di Scienze della Terra

Via La Pira, 4

50121 FIRENZE - ITALY

Tel/Fax +390552382146

E-mail: cmanetti@geo.unifi.it

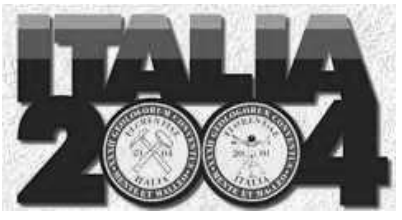

